\title{
PENERAPAN PENGELOMPOKAN SISWA BERDASARKAN PRESTASI DI JENJANG SEKOLAH DASAR
}

\author{
Doddy Hendro Wibowo
}

\author{
Fakultas Psikologi Universitas Kristen Satya Wacana \\ J1. Diponegoro 52-60 Salatiga \\ doddy.hendro@gmail.com
}

\begin{abstract}
Students who have high academic grades in school need to be grouped into one class. This paradigm is still inherent in the community and teachers usually use this paradigm to group students who have high academic achievement in the classroom (ability grouping). This research is to provide an overview of the attitudes of teachers, students, and parents with regard to the implementation of ability grouping based on academic achievement. This research is quantitative descriptive study. The study was conducted in one of the public school at Semarang, Central Java, Indonesia, grade IV and V, involving 6 classroom teachers grade IV and Grade V, 166 students and 166 parents. Data was collected using questionnaires and interviews. Result shows, teacher class A (high achievement) agrees, teacher class B (average achievement) and C (low achievement) do not agree with ability grouping. Most students in grade A, B and C agree with ability grouping. Parents of the class A agree, while the parents of the class $\mathrm{B}$ and $\mathrm{C}$ do not agree with ability grouping.
\end{abstract}

Keywords: ability grouping, attitudes of teachers, students and parents, academy achievement, elementary school.

\begin{abstract}
Abstrak
Siswa yang memiliki nilai akademik yang tinggi di sekolah perlu dikelompokkan ke dalam satu kelas. Paradigma ini masih melekat di masyarakat dan guru biasanya menggunakan paradigma ini untuk mengelompokkan siswa yang memiliki prestasi akademik tinggi di kelas. Penelitian ini bertujuan untuk memberikan gambaran tentang sikap guru, siswa, dan orang tua berkaitan dengan pelaksanaan pengelompokan siswa berdasarkan prestasi akademik. Penelitian dilakukan pada siswa, guru dan orang tua di salah satu SD Negeri di Kota Semarang. Populasi dalam penelitian ini adalah siswa kelas IV dan V sejumlah 166 siswa, 166 orang tua siswa, dan 6 orang guru kelas IV dan V. Data dikumpulkan dengan menggunakan kuesioner dan wawancara. Hasilnya menunjukkan, Guru kelas A (Kelas tinggi) setuju dengan pengelompokkan siswa, Guru kelas B (Kelas sedang) dan Guru Kelas C (Kelas rendah) tidak setuju dengan pengelompokan siswa berdasarkan prestasi. Siswa kelas $\mathrm{A}, \mathrm{B}$ dan $\mathrm{C}$ setuju dengan pengelompokan siswa berdasarkan prestasi. Orang tua dari kelas A menyatakan setuju, sedangkan orang tua dari kelas B dan C menyatakan tidak setuju dengan adanya pengelompokan siswa berdasarkan prestasi akademik.
\end{abstract}

Kata kunci: ability grouping, sikap guru, siswa dan orang tua siswa, prestasi akademik, sekolah dasar

\section{PENDAHULUAN}

Siswa yang pandai adalah siswa yang memiliki nilai akademis yang tinggi di sekolah. Berlawanan dengan hal tersebut, siswa yang bodoh adalah siswa yang tidak menunjukkan prestasi di kelas, tidak bisa mengikuti pelajaran dan sering membuat kekacauan di kelas. Hal ini masih sering terjadi di masyarakat luas dan cara pandang ini digunakan oleh guru untuk membuat pengelompokkan bagi siswa berdasarkan prestasi akademik (nilai) yang diraih. Pengelompokan atau grouping didasarkan atas pandangan bahwa peserta didik mempunyai kesamaan kemampuan. Salah satu bentuk pengelompokkan yang sering dilakukan adalah pengelompokkan siswa berdasarkan kemampuan akademis atau prestasi yang diperoleh di kelas. Hal ini biasa disebut dengan ability grouping/ achievement grouping (Mitchun dalam 
Imron, 1994). Ability grouping merujuk pada suatu bentuk pengelompokkan yang dilakukan oleh guru, pejabat sekolah, atau pengambil kebijakan yang bertujuan untuk mengelompokkan siswa ke dalam kelas atau sekolah berdasarkan pada kemampuan mereka (Cheung \& Rudowicz, 2003). Pelaksanaan ability grouping menempatkan siswa pada suatu anggapan bahwa anak pandai harus bergabung dengan anak pandai dan anak kurang pandai harus bergabung dengan anak kurang pandai. Seleksi pandai dan kurang pandai dilakukan melalui nilai raport. Biasanya guru mengambil beberapa siswa peringat atas di satu kelas, kemudian menjadikan satu dengan siswa lain yang berperingkat atas dari kelas lain.

Adodo dan Agbaweya (2011), menyatakan bahwa pengelompokkan siswa berdasarkan kemampuan kognitif dapat memberikan keuntungan yakni: meningkatan prestasi siswa, memudahkan guru dalam mengajar di kelas, memudahkan guru untuk mengendalikan proses pemberian instruksi, dan memudahkan guru memberikan penguatan kepada siswa yang berprestasi tinggi dan berprestasi rendah, siswa yang berprestasi rendah merasa lebih nyaman ketika berada bersama teman-teman yang memiliki kemampuan setara, siswa yang berprestasi tinggi juga dapat saling menjaga dan mendukung minat mereka, siswa bisa saling menghargai dan berpartisipasi dalam kerja kelompok antar siswa, membantu guru dalam menyesuaikan bahan dan metode pengajaran yang sesuai dengan kebutuhan dan tingkat siswa, pemanfaatan waktu, ruang dan bahan bagi siswa dapat menjadi lebih optimal, dan siswa dapat bekerja secara cepat atau lambat sesuai dengan tingkat kemampuan kelas mereka.

Hornby dan Witte (2014), menjelaskan bahwa adanya pengelompokkan kelas berdasarkan kemampuan akademik memiliki manfaat yaitu memenuhi kebutuhan pendidikan siswa, meningkatkan pencapaian siswa, memenuhi keinginan orangtua bahwa anaknya ingin dikelompokkan dengan siswa yang memiliki kemampuan sama, dan dengan pengelompokkan siswa guru dapat menggunakan sarana pembelajaran secara maksimal. Sedangkan kekurangan dari pengelompokkan siswa berdasarkan kemampuan adalah menurunkan harapan guru terhadap pencapaian prestasi siswa, siswa di kelas rendah kurang bisa untuk menjadi model untuk pembelajaran, adanya stigma negatif bagi kelas rendah, kesulitan mengatur jam pelajaran di sekolah, dan seringnya muncul permasalahan perilaku di kelompok siswa kelas rendah, menurunkan kemampuan siswa dalam menyampaikan ide pada siswa di kelas tinggi, dan bahkan orang tua merasa cemas bahwa anak mereka akan salah dikelompokkan oleh guru.

Asumsi penerapan ability grouping adalah bahwa siswa yang berprestasi akademik memerlukan layanan pembelajaran yang berbeda dengan siswa yang kurang memiliki prestasi akademik. Anggapan ini didasarkan bahwa siswa yang berprestasi akademik memiliki kemampuan lebih cepat menerima pelajaran dibandingkan dengan siswa yang kurang berprestasi akademik. Jika kedua kelompok yang berbeda tingkat prestasi akademik ini dijadikan satu, maka akan terjadi ketimpangan dalam penerimaan pelajaran. Bentuk ketimpangan itu adalah siswa yang cepat menguasai pelajaran harus menunggu pada siswa yang kurang cepat menguasai pelajaran sampai siswa tersebut menguasai pelajaran.

Gamoran (dalam Wong dan Watkins, 2001), menyatakan kekurangan dari ability grouping yaitu bahwa apabila dilakukan pengelompokkan kelas maka jarak antara siswa yang memiliki kemampuan tinggi 
dan siswa yang memiliki kemampuan rendah akan semakin luas. Hasil penelitian Hornby, Witte dan Mitchel (2011), menunjukkan bahwa pengelompokkan kelas berdasarkan kemampuan (kelas homogen) bukan merupakan salah satu cara yang efektif dalam meningkatkan prestasi akademik siswa. Sebuah penelitian mengenai pengelompokkan kelas yang dilakukan di tingkat perguruan tinggi oleh Bahar (2015), menyatakan bahwa tidak ada pengaruh dalam proses belajar mereka dan tidak ada perubahan dalam perilaku belajar serta kegiatan sosial dan persahabatan antar siswa juga tidak ada perubahan.

Chisaka dan Vakalisa (2003), memberikan hasil penelitian berkaitan dengan evaluasi dilakukannya pengelompokkan kelas berdasarkan kemampuan akademik. Hasil penelitian tersebut menunjukkan bahwa siswa yang berada di kelas tinggi mengalami pengabaian oleh guru. Penelitian ini juga menunjukkan bahwa adanya pengelompokkan kelas bisa disalahgunakan oleh guru. Penyalahgunaan tersebut antara lain guru tidak mau mengajar di kelas tinggi karena siswa sudah dianggap cukup cerdas untuk lulus ujian tanpa adanya bimbingan dari guru. Penelitian ini juga menunjukkan bahwa dengan adanya pengelompokkan kelas tidak meningkatkan pengajaran atau instruksi dan pembelajaran. Sebaliknya mendorong stratifikasi sosial yang tidak sehat dan kurangnya relasi sosial di antara kelas tinggi dan rendah. Wong dan Watkins (2001), menunjukkan kelemahan pengelompokkan kelas berdasarkan hasil penelitiannya di Hong Kong bahwa kelas yang dikelompokkan berdasarkan kemampuan kognitif tidak mampu memaksimalkan siswa dalam pengembangan harga diri, dan siswa yang dikelompokkan di kelas dengan kemampuan rata-rata, sering mengalami pengabaian oleh guru.

Ability grouping akan memberikan kondisi pada suasana belajar yang ideal dan kondusif untuk mencapai tujuan pragmatis dalam belajar. Hal ini tampak dari hasil evaluasi belajar siswa yang memiliki kemampuan sama akan dengan mudah menerima materi pelajaran.

Potensi akademik yang homogen akan memberikan respon hasil belajar yang homogen pula. Guru dengan mudah menyampaikan materi, selanjutnya siswa akan menanggapi dalam proses belajar dengan lebih mudah. Pada akhirnya prestasi akademik siswa akan mudah termonitor dan mudah pula melakukan perlakukan-perlakuan khusus dalam rangka perbaikan atau pengayaan. Sementara di satu sisi, guru dengan mudah memberikan pelajaran, karena kemampuan siswa yang sama. Namun di sisi lain, guru juga harus bekerja keras menghadapi kelas yang kurang karena potensi dasar siswa yang dimiliki bukan pada kemampuan akademik ditambah dengan adanya asumsi bahwa biasanya kelas yang kurang diikuti pula dengan perilaku yang cenderung kurang.

Siswa yang berkemampuan rendah tidak akan mampu berpartisipasi secara maksimal jika mereka berada dalam kelompok yang juga berkemampuan rendah. Siswa yang berkemampuan tinggi tidak akan menurun performanya jika harus bekerja sama dengan siswa berkemampuan rendah, dan siswa yang berkemampuan sedang juga dapat bekerja sama secara maksimal asalkan mereka berada dalam satu kelompok atau dalam kelompok yang berkemampuan berbeda (Huda, 2012). Demikian juga dengan penilaian yang dilakukan (hasil raport) diperoleh dari test yang notabene menggunakan kemampuan verbal/ bahasa. Hasilnya, apabila dilihat adanya ability grouping berdasarkan prestasi siswa merupakan bentuk penggolongan siswa yang memiliki kemampuan/ kecerdasan 
yakni kecerdasan linguistik dan logika matematik. Sedangkan siswa yang tidak memiliki kecerdasan tersebut, ditempatkan di kelas yang kurang dan dianggap sebagai anak yang "bodoh". Dari pandangan ini, ability grouping sudah jauh meninggalkan pandangan bahwa siswa mempunyai kecerdasan yang berbeda-beda sehingga tidak bisa disamakan antara siswa yang satu dengan siswa yang lain. Tiap siswa mempunyai kemampuan kognitif yang istimewa, sehingga rasanya kurang adil ketika terjadi pengelompokkan siswa yang berdasarkan pada kemampuan verbal dan matematika saja.

Fungsi pendidikan adalah membimbing siswa ke arah suatu tujuan yang kita nilai tinggi. Pendidikan yang baik adalah usaha yang berhasil membawa semua siswa kepada tujuannya itu, apa yang diajarkan hendaknya dipahami sepenuhnya oleh siswa (Nasution, 2003). Tujuan guru mengajar adalah agar bahan yang disampaikkannya dikuasai sepenuhnya oleh semua siswa, bukan hanya oleh beberapa siswa saja yang memiliki nilai yang tinggi. Mendasarkan hasil pelajaran pada kurva normal, yakni kemampuan siswa yang memiliki peringat tinggi (nilai tinggi), berarti bahwa hanya sebagian kecil saja dari siswa yang diharapkan dapat memahami materi yang disampaikan guru sepenuhnya. Dengan melihat hasil mengajar secara kurva normal sesungguhnya merupakan suatu kegagalan, karena sebagian besar siswa tidak mengerti betul apa yang diajarkan. Guru yang baik harus meninggalkan bentuk kurva normal sebagai bentuk keberhasilan proses belajar mengajar (Nasution, 2003).

Setiap sekolah memiliki kebijakan sendiri dalam pengelolaan kelas, seperti misalnya yang terjadi di salah satu SD Negeri di Semarang yang menjadi Populasi Penelitian. Kepala sekolah, sebagai pengambil keputusan, memiliki kebijakan untuk mengelola kelas berdasarkan kemampuan akademik siswa. Terutama dilakukan di kelas IV dan kelas V, pengelompokan dibagi menjadi 3 kelas, dimana kelas A merupakan kelas yang memiliki kemampuan akademik paling baik, kelas B berkemampuan sedang dan kelas $\mathrm{C}$ berkemampuan kurang.

Pengelompokkan ini pada awalnya bertujuan untuk menggabungkan guru dan siswa dari 2 SD yang berbeda. Untuk mengurangi kecenderungan berkelompok guru dan siswa antara SD pertama dan SD kedua, maka kepala sekolah menggabungkan siswa, supaya tidak ada kelompok diantara guru dan siswa. Pertimbangan lain diberlakukan pengelompokkan, Guru menganggap adanya ketimpangan ketika proses pembelajaran di kelas. Siswa yang pandai cepat menyelesaikan tugas, sementara siswa yang kurang tertinggal oleh teman yang pandai. Hal ini menyebabkan kepala sekolah mengambil keputusan, mengelompokkan siswa berdasarkan kemampuan siswa, penggunaan nilai raport sebagai acuan dalam pembagian kelompok kelas. Dari 3 tahun berjalan, kepala sekolah memberikan evaluasi bahwa dengan adanya pengelompokkan siswa, jumlah siswa yang masuk ke SMP unggulan tanpa mengikuti seleksi semakin meningkat. Dan hal ini dianggap merupakan prestasi bagi sekolah. Namun, adanya pengelompokkan juga seringkali menuai protes dari orang tua yang anaknya masuk ke kelas rendah.

Berdasarkan uraian di atas, maka dirumuskan tujuan dari penelitian ini, yaitu ingin melihat bagaimana sikap dan permasalahan yang dihadapi oleh Guru, Murid dan Orang tua siswa di dalam pelaksanaan pengelompokkan siswa (ability grouping) berdasarkan prestasi akademik. 


\section{METODE}

Jenis penelitian yang digunakan merupakan penelitian deskriptif. Penelitian deskriptif melaporkan keadaan objek atau subjek yang diteliti sesuai dengan apa adanya. Penelitian deskriptif pada umumnya dilakukan dengan tujuan utama, yaitu menggambarkan secara sistematis fakta dan karakteristik objek atau subjek secara tepat (Sukardi, 2003).

Populasi penelitian dipilih di salah satu SD Negeri di Semarang. SD ini telah melaksanakan pengelolaan kelas dengan menggunakan teknik ability grouping. Dasar pengelompokkan kelas yang dilakukan oleh Kepala Sekolah dan Guru adalah nilai raport semester. Berdasarkan nilai tersebut, Kepala Sekolah membagi siswa menjadi tiga kelas, yaitu: siswa dengan prestasi akademik tinggi (nilai raport tinggi), siswa dengan prestasi akademik sedang (nilai raport sedang) dan siswa dengan prestasi akademik rendah (nilai raport rendah).

Teknik pengambilan sampel menggunakan teknik purposive sampling atau sampling bertujuan. Teknik pengambilan sampel berdasarkan pada tujuan tertentu (Sukardi, 2003). Total seluruh partisipan dalam penelitian ini yaitu guru kelas IV dan Kelas V (6 orang), siswa kelas IV dan Kelas V (166 orang) dan orang tua siswa kelas IV dan Kelas V (166 orang).

\section{Prosedur Pengambilan data dari Guru Kelas}

Sampel Guru Kelas IV dan V terdiri dari 3 guru perempuan untuk kelas IV (Kelas tinggi, kelas Sedang dan kelas rendah) dan 2 guru perempuan serta 1 guru laki-laki (Kelas tinggi, kelas sedang dan kelas rendah). Latar belakang pendidikan guru kelas adalah Sarjana Pendidikan. Angket yang diberikan bertujuan untuk mengetahui sikap guru terhadap pengelompokkan siswa berdasarkan prestasi akademik, permasalahan yang dihadapi di dalam kelas, dan saran berkaitan dengan pengelompokkan kelas. Bentuk pertanyaan berupa pertanyaan tertutup dan terbuka. Angket dengan pertanyaan tertutup dengan menggunakan pilihan jawaban: Sangat Setuju (SS), Setuju (S), Tidak Setuju (TS), Sangat Tidak Setuju (STS). Contoh pertanyaan dalam bentuk pernyataan misalnya: "Adanya Pengelompokkan kelas, membuat Guru menyusun Rencana Program Pembelajaran berdasarkan kemampuan akademik siswa"; Adanya pengelompokkan kelas, membuat Guru menyampaikan materi di kelas sesuai sesuai dengan kemampuan akademik siswa. Sedangkan bentuk pertanyaan terbuka dengan menggunakan pertanyaan berbentuk essay, misalnya: "Bagaimana pendapat anda berkaitan pelaksanaan Ability Grouping ini?" atau "Apa saran terhadap pelaksanaan Ability Grouping?"

Sebagai data sekunder dilakukan proses wawancara yang dilakukan kepada guru kelas. Wawancara dilakukan secara kelompok hanya dilakukan kepada guru kelas dengan mempertimbangkan bahwa Guru kelas merupakan orang yang melaksanakan praktik pembelajaran di kelas, dan secara khusus memahami dinamika kemampuan dan perilaku siswa yang berkemampuan tinggi, sedang dan rendah. Wawancara dilakukan kepada Seluruh Guru Kelas IV dan V yang berjumlah 6 orang. Wawancara dilakukan setelah jam pembelajaran di sekolah selesai atau ketika Guru tidak mengajar. Bentuk pertanyaan yaitu pertanyaan terbuka, misalnya "Bagaimana pandangan anda sebagai Guru kelas tentang ability grouping yang sudah dilaksanakan ini?’”. Konsep diskusi kelompok (Focus Group Disscussion) dilakukan oleh Peneliti untuk memperoleh keluasan dan kedalaman jawaban yang diberikan oleh Guru Kelas. 
Prosedur Pengambilan data dari Siswa

Sampel Siswa kelas IV dan V sejumlah 166 siswa yang terdiri dari siswa kelas IV Tinggi (28 siswa); Siswa kelas IV sedang (30 siswa); Siswa kelas IV rendah (24 siswa); Siswa kelas V tinggi (32 siswa); Siswa kelas V sedang (26 siswa) dan Siswa kelas V rendah (26 siswa). Angket berisi pertanyaan tentang sikap siswa terhadap pengelompokkan kelas, permasalahan yang terjadi antar siswa di kelas Tinggi, kelas sedang dan kelas rendah, saran untuk pelaksanaan pengelompokkan kelas.

Angket yang diberikan merupakan angket dengan pertanyaan tertutup dan terbuka. Angket dengan pertanyaan tertutup dengan menggunakan pilihan jawaban: Sangat Setuju (SS), Setuju (S), Tidak Setuju (TS), Sangat Tidak Setuju (STS). Contoh pernyataan tertutup misalnya: "Saya merasa dengan adanya pengelompokkan kelas, ada persaingan untuk mendapat nilai baik antara teman di kelas"; dengan adanya pengelompokkan kelas, Guru mendampingi bila siswa mengalami kesulitan dalam memahami pelajaran". Angket dengan pertanyaan terbuka dengan menggunakan pertanyaan berbentuk essay, misalnya: "Bagaimana pendapat anda berkaitan pelaksanaan Ability Grouping ini?" atau "Apa saran terhadap pelaksanaan Ability Grouping?". Pengisian angket dilakukan ketika ijin sudah diberikan oleh Guru Kelas kemudian peneliti masuk ke kelas dan atau ketika jam pelajaran kosong. Siswa mengisi angket di sekolah. Peneliti mendampingi dan memberikan penjelasan kepada siswa ketika mengisi angket.

\section{Prosedur Pengambilan data dari Orang Tua}

Sampel orangtua yang terdiri dari 166 orang tua siswa, dimana salah satu perwakilan orang tua (ayah atau ibu) bisa memberikan jawaban untuk pertanyaan angket. Latar belakang orang tua siswa beragam yakni pada sektor formal dan informal misalnya Guru, Karyawan Pabrik, Pegawai Negeri atau Wiraswasta. Angket yang diberikan merupakan angket dengan pertanyaan campuran yakni pertanyaan tertutup dan terbuka.

Angket dengan pertanyaan tertutup dengan menggunakan pilihan jawaban: Sangat Setuju (SS), Setuju (S), Tidak Setuju (TS), Sangat Tidak Setuju (STS). Bentuk pertanyaan berupa pernyataan misalnya "Adanya pengelompokkan kelas, muncul pandangan bahwa ada perbandingan kemampuan anak berdasarkan prestasi diantara kelas A, B dan C"; Adanya pengelompokkan kelas menimbulkan kesenjangan antara siswa kelas tinggi, siswa kelas sedang dan siswa kelas rendah". Angket dengan pertanyaan terbuka menggunakan pertanyaan berbentuk essay, misalnya: "Bagaimana pendapat anda berkaitan pelaksanaan Ability Grouping ini?" atau "Apa saran terhadap pelaksanaan Ability Grouping?". Angket kepada orangtua dititipkan kepada siswa untuk dibawa pulang, dan diisi oleh perwakilan orang tua (Ayah atau Ibu) di rumah dan keesokan hari, siswa diminta mengumpulkan kembali angket di sekolah.

Tabel 1.

Distribusi jumlah guru, siswa dan orang tua.

\begin{tabular}{lllll}
\hline \multicolumn{2}{l}{ Jumlah Kelas } & \multicolumn{2}{l}{ Tinggi } & \multicolumn{2}{l}{ Sedang Rendah } \\
\hline Guru & IV & 1 & 1 & 1 \\
& V & 1 & 1 & 1 \\
Siswa & IV & 28 & 30 & 24 \\
& V & 32 & 26 & 26 \\
Orang & IV & 28 & 30 & 24 \\
tua & V & 32 & 26 & 26 \\
\hline
\end{tabular}

Data yang diperoleh dari lapangan diolah berdasarkan kategori Guru, Siswa dan Orang tua. Setiap jawaban dari pernyataan, dikelompokkan berdasarkan jawaban, dihitung jumlahnya dan dilakukan persensentase. Untuk data kualitatif yang diperoleh berdasarkan hasil wawancara dengan Guru, digunakan sebagai data 
sekunder dan data pelengkap untuk pembahasan.

\section{HASIL DAN PEMBAHASAN}

Berdasarkan hasil analisis data, diperoleh data mengenai sikap guru kelas terhadap pelaksanaan ability grouping seperti yang disampaikan dalam gambar 1 .

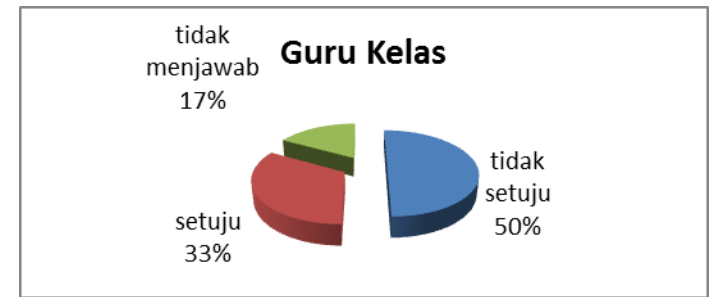

Gambar 1.

Sikap guru kelas mengenai pelaksanaan Ability Grouping

Berdasarkan hasil angket yang disebar kepada 6 Guru Kelas A, B, dan C, diketahui bahwa pelaksanaan pengelompokkan siswa apabila dilihat dari guru kelas yang merupakan penyelenggara proses pembelajaran, menyatakan bahwa $50 \%$ guru kelas menyatakan tidak setuju dengan adanya pengelompokan siswa. Ketidaksetujuan ini terutama berasal dari guru kelas yang mengampu kelas B dan C (kelas rata-rata dan kelas rendah), sedangkan guru yang mengampu kelas A (kelas tinggi) menyatakan setuju dengan adanya pengelompokan ini. Dari pendapat guru yang menyatakan tidak setuju, memberikan alasan bahwa seharusnya siswa di dalam kelas memiliki karakteristik kemampuan secara beragam, ada siswa yang pandai, sedang dan kurang. Guru kelas menyatakan bahwa siswa tidak mampu bersaing secara sehat untuk memperoleh nilai yang lebih baik dan guru kelas merasa terbebani ketika mengajar di kelas yang kurang. Sedangkan dari guru kelas yang menyetujui pengelompokan siswa menyatakan bahwa nilai siswa dapat meningkat dan lebih mudah dalam menyampaikan materi.

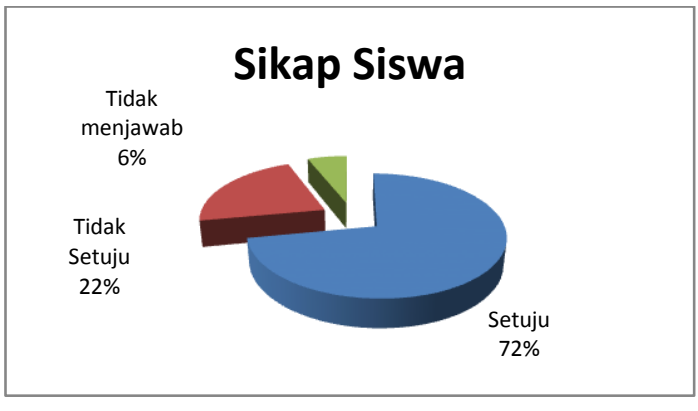

Gambar 2.

Sikap Siswa mengenai Pelaksanaan Ability Grouping

Dari gambar 2 dapat diketahui berdasarkan angket yang diberikan kepada 166 siswa, Kelas A, B dan C, diketahui sikap siswa terhadap pelaksanaan pengelompokan siswa bila dilihat dari sudut pandang siswa, sejumlah $72 \%$ siswa menyatakan setuju dengan pengelom-pokkan siswa. Alasan menyetujui ability grouping yaitu: menambah pengetahuan/ kepandaian dan percaya diri, dapat memisahkan anak pandai, kurang pandai dan tidak pandai, memberikan semangat untuk belajar dengan giat dan menambah teman-teman baru. Sedangkan 22\% siswa yang tidak setuju menyatakan alasan membuat terpisah dengan teman-teman yang disukai, dan siswa menganggap bahwa seharusnya semua kelas sama saja, tidak ada pembedaan.

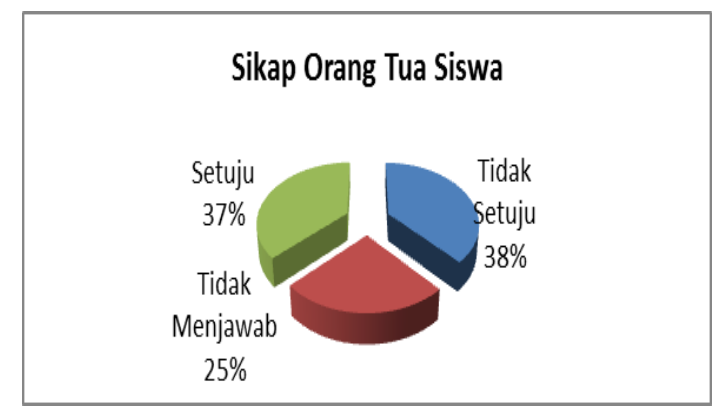

Gambar 3.

Sikap Orangtua Siswa terhadap Pelaksanaan Ability Grouping

Gambar 3 memberikan gambaran bahwa berdasarkan angket yang diberikan kepada 166 orang tua siswa kelas A, B dan C, sikap orang tua siswa (Kelas A, B dan C) 
sejumlah $37 \%$ menyatakan setuju dengan pengelompokan siswa. Alasan orang tua menyetujui pengelompokan siswa adalah dapat menambah motivasi siswa, tanggung jawab untuk belajar dan menjadi yang terbaik dan mempermudah dalam proses belajar dan mengajar. Hal ini didukung dengan orang tua yang memberikan selalu dorongan kepada anaknya untuk tetap berada di kelas A. Sejumlah $38 \%$ orang tua siswa (kelas A, B dan C) menyatakan tidak setuju.

Menurut pandangan orang tua siswa yang tidak setuju, memberikan masukan yaitu adanya pengelompokan kelas dimulai dari kelas I, sehingga anak tetap berada di kelas yang sama hingga kelas 6 atau lulus; Lebih diperhatikan pada kelas yang kemampuannya kurang, yakni kelas C; Pengelompokan kelas diiukuti dengan kemampuan guru yang mumpuni, kreatif sehingga mampu membawa anak didik menjadi lebih baik; Guru kelas dapat memberitahu kelebihan dan kekurangan siswa kepada orang tua; Menambah kegiatan ekstrakurikuler yang lebih bermanfaat terutama untuk meningkatkan soft skill pada anak; Dasar dari adanya pengelompokan kelas harus dilakukan dengan cermat dan tepat berdasarka hasil penelitian; Apabila ada pengelompokan berdasarkan prestasi, sebaiknya peserta didik tidak mengetahui bahwa pengelompokan berdasarkan prestasi; Memberikan fasilitas yang sama antara kelas A, B dan C; Memberikan les tambahan bagi kelas yang kurang.

SD Tinjomoyo 01 merupakan gabungan dari 2 Sekolah Dasar di daerah Tinjomoyo Semarang. Kepala sekolah, sebagai pengambil keputusan, memiliki kebijakan untuk mengelola kelas. Ketika 2 Sekolah tersebut digabungkan, Kepala Sekolah membuat kelas berdasarkan klasifikasi kemampuan akademik dengan mengacu pada nilai raport siswa. Kepala Sekolah beranggapan bahwa untuk memudahkan kedua siswa dari sekolah dapat cepat membaur, maka Kepala Sekolah menggabungkan semua siswa dan membagi siswa ke dalam tiga kelas sesuai dengan kemamuan yang dimiliki (nilai raport). Berdasarkan nilai raport tersebut diperoleh 3 kelas yakni kelas A merupakan kelas yang memiliki kemampuan akademik tinggi, kelas B berkemampuan akademik sedang dan kelas $\mathrm{C}$ berkemampuan akademik kurang. Pengelompokan ini pada awalnya bertujuan untuk menggabungkan guru dan siswa dari 2 SD yang berbeda. Untuk mengurangi kecenderungan berkelompok guru dan siswa antara SD pertama dan SD kedua, maka kepala sekolah menggabungkan siswa, supaya tidak ada kelompok diantara guru dan siswa. Pertimbangan lain diberlakukan pengelompokan, Guru menganggap adanya ketimpangan ketika proses pembelajaran di kelas. Siswa yang pandai cepat menyelesaikan tugas, sementara siswa yang kurang tertinggal oleh teman yang pandai. Kepala Sekolah melakukan evaluasi setelah pengelompokan kelas berjalan selama 3 tahun, kepala sekolah mengambil kesimpulan bahwa dengan adanya pengelompokan siswa, jumlah siswa yang masuk ke SMP unggulan tanpa mengikuti seleksi semakin meningkat dan hal ini merupakan prestasi bagi sekolah.

Menurut Abdurrahman (1999), ada empat jenis interaksi kompetitif yang efektif untuk mencapai tujuan belajar, yaitu: 1 . Kompetisi antar individu yang berkemampuan seimbang, 2. Kompetisi antar kelompok yang berkekuatan relatif sama, 3. Kompetisi dengan standar nilai minimum, 4. Kompetisi dengan diri sendiri. Kompetisi antarindividu atau antar kelompok yang berkemampuan seimbang sangat sulit dilakukan dan tidak mungkin benar-benar terwujud. 
Pembagian kelas berdasarkan kemampuan akademik siswa merupakan bentuk pembagian kelas yang dapat meningkatkan kompetisi antar siswa. Alasan utama seorang guru memilih interaksi pembelajaran kompetitif umumnya untuk membangkitkan motivasi belajar. Hal ini tidak salah karena siswa memiliki dorongan untuk berprestasi (needs of achievement). Namun guru sering lupa bahwa kompetisi antar individu yang tidak seimbang dapat menimbulkan keputusasaan bagi yang lemah dan kebosanan bagi yang kuat. Oleh karena itu guru perlu hatihati dalam penerapan interaksi kompetititf dalam kegiatan pembelajaran (Abdurrahman, 1999). Untuk itu jika guru ingin menciptakan kompetisi antar individu, maka individu yang saling berkompetisi harus memiliki peluang yang sama untuk kalah dan menang dan kompetisi hanya dilakukan untuk selingan yang menyenangkan (Abdurrahman, 1999).

Guru kelas tinggi menyatakan setuju terhadap pengelompokan kelas berdasarkan prestasi siswa dengan alasan dapat meningkatkan prestasi belajar, terbukti dari siswa yang hasil sebelumnya kurang, kemudian dapat menyesuaikan diri sehingga hasilnya lebih baik serta lebih mudah untuk menyampaikan materi dan hasilnya pun lebih baik. Sedangkan Guru dari kelas rata-rata dan kelas rendah (kelas B dan C) menyatakan tidak menyetujui pengelompokan kelas dengan alasan karena seharusnya siswa di dalam kelas ada siswa yang pandai, sedang dan kurang, karena adanya pengelompokan kelas, siswa tidak mampu bersaing secara sehat untuk memperoleh nilai yang lebih baik dan guru kelas merasa terbebani untuk mengajar di kelas yang rata-ratanya kurang. Berdasarkan dari hasil wawancara dengan guru kelas, disimpulkan bahwa Guru di kelas Tinggi menyetujui adanya pengelompokan kelas karena memu- dahkan di dalam proses pembelajaran, karena berkaitan dengan kemampuan siswa yang tinggi pula. Siswa di kelas juga aktif dan mampu berdiskusi. Namun berkebalikan dengan Guru di kelas sedang dan rendah, mereka merasa keberatan karena merasa berat dan terutama kemampuan siswa yang terbatas, cenderung pasif dan mendampingi bagi siswa yang kurang. Hal ini seharunya bisa menjadi masukan kepada kepala sekolah apabila di kemudian hari ada program pengelompokan siswa, guru kelas perlu di rotasi sehingga guru kelas rendah juga bisa merasakan mengajar di kelas tinggi.

Guru hendaknya juga memahami bahwa tiap siswa memiliki laju perkembangan fungsi motorik, kognitif, maupun afektif yang berbeda - beda. Siswa yang mengalami kelambatan atau kurang dalam prestasinya dipandang sebagai/ hanya bersifat sementara. Hal ini biasanya terjadi karena anak didorong dan dipaksa oleh lingkungan sosial untuk mencapai kinerja akademik (academic performance) sebelum mereka siap untuk itu (Abdurrahman, 1999). Merupakan suatu hal yang tidak adil apabila siswa belum siap, atau belum matang kemudian dikategorikan dan dimasukkan ke dalam kelas kurang. Apabila hal ini bisa diterapkan, maka pandangan yang muncul dimana kelas $\mathrm{C}$ sebagai kelas kurang tidak akan muncul.

Orang tua dari kelas Tinggi (kelas A) menyetujui pengelompokan kelas dengan alasan: dapat menambah motivasi siswa, tanggung jawab untuk belajar dan menjadi yang terbaik, dan mempermudah dalam proses belajar dan mengajar. Sedangkan orang tua dari kelas rata-rata (kelas B) dan kelas rendah (Kelas C) berpendaat bahwa dengan adanya pengelompokan siswa akan mengakibatkan menimbulkan kesenjangan/ perbandingan antar siswa, menimbulkan rasa minder, kurang percaya diri, karena dianggap sebagai siswa bodoh, 
menyebabkan pengabaian oleh Guru di kelas rendah dan motivasi siswa tidak terpacu karena berkumpul dengan siswa yang kemampuannya sama. Ketika sekolah melakukan pengelompokan siswa, orang tua mengharapkan guru dapat lebih memperhatikan pada kelas yang kemampuannya kurang, Pengelompokan kelas diiukuti dengan kemampuan guru yang mumpuni, kreatif sehingga mampu membawa siswa menjadi lebih baik, menambah kegiatan ekstrakurikuler yang lebih bermanfaat terutama untuk meningkatkan soft skill, dasar dari adanya pengelompokan kelas harus dilakukan dengan cermat dan tepat berdasarkan hasil penelitian, apabila ada pengelompokan berdasarkan prestasi, sebaiknya siswa tidak mengetahui bahwa mereka dikelompokkan berdasarkan prestasi dan Guru dapat memberikan les tambahan bagi siswa di kelas rendah.

Secara umum, pelaksanaan pengelompokkan kelas yang sudah berjalan selalu menimbulkan keadaan pro dan kontra. Namun pihak sekolah memiliki kebijakan tertentu yang menjadi dasar dan tentunya kebijakan ini bertujuan untuk memberikan pelayanan yang terbaik bagi siswa. Pelaksanaan ability grouping juga memang tidak dapat dipisahkan dari adanya pandangan bahwa kelas A sebagai kelas pandai, sementara kelas C sebagai kelas kurang. Pandangan ini disetujui oleh guru, siswa dan orang tua. Penerapan program ability grouping harus bisa mengubah paradigma semua penyelenggara kegiatan belajar mengajar, bahwa setiap siswa mempunyai kecerdasan majemuk, tidak hanya terbatas pada kecerdasan bidang akademik saja.

\section{KESIMPULAN}

Pelaksanaan pengelompokan siswa berdasarkan prestasi akademik apabila dilihat dari sudut pandang guru bahwa guru dari kelas A menyetujui adanya pengelompokan kelas, sementara guru dari kelas $\mathrm{B}$ dan $\mathrm{C}$ tidak menyetujui adanya pengelompokan kelas. Guru kelas tinggi menyatakan setuju terhadap pengelompokan kelas karena dapat meningkatkan prestasi belajar siswa, terbukti dari anak yang hasil sebelumnya kurang, kemudian dapat menyesuaikan diri sehingga hasilnya lebih baik, lebih mudah untuk menyampaikan materi dan nilai yang diperoleh lebih tinggi. Guru dari kelas ratarata dan kelas rendah (kelas B dan C) menyatakan tidak setuju karena seharusnya siswa di dalam kelas ada siswa yang pandai, sedang dan kurang, pengelompokkan kelas menyebabkan anak tidak mampu bersaing secara sehat untuk memperoleh nilai yang lebih baik dan guru kelas merasa terbebani untuk mengajar di kelas yang rata-ratanya kurang.

Pelaksanaan pengelompokan siswa berdasarkan prestasi apabila dilihat dari sudut pandang siswa menyatakan bahwa siswa setuju dengan pengelompokan. Dengan pengelompokan siswa juga membuat siswa menjadi terpacu dalam belajar dalam arti menambah motivasi untuk masuk ke kelas A.

Pengelompokan siswa berdasarkan prestasi apabila dilihat dari sudut pandang orang tua murid menyatakan bahwa orang tua dari kelas A setuju sedangkan orang tua siswa kelas B dan C tidak setuju. Orang tua siswa kelas A menyatakan bahwa dengan pengelompokan siswa, dapat menambah motivasi siswa dalam belajar, tanggung jawab untuk belajar dan menjadi yang terbaik, dan mempermudah dalam proses belajar dan mengajar. Orang tua dari kelas $\mathrm{B}$ dan $\mathrm{C}$ menyatakan pengelompokan siswa akan mengakibatkan kesenjangan/ perbandingan antar siswa, menimbulkan rasa minder, kurang percaya diri, karena dianggap sebagai anak bodoh, menyebabkan pengabaian oleh 
Guru di kelas rendah dan motivasi anak tidak terpacu karena berkumpul dengan anak yang kemampuannya sama. Orang tua berharap ketika sekolah melakukan pengelompokan siswa, orang tua mengharapkan guru dapat lebih memperhatikan pada kelas yang kemampuannya kurang, dan Guru dapat memberikan les tambahan bagi kelas yang kurang.

Berdasarkan kesimpulan tersebut, dapat diberikan saran kepada pihak-pihak terkait, diantaranya bagi sekolah: Kepala Sekolah secara khusus melalui guru kelas memperhatikan siswa di kelas $\mathrm{B}$ dan $\mathrm{C}$, dalam hal ini mengorganisasikan apa yang menjadi kelebihan/ potensi yang dimiliki siswa kelas B dan C untuk dapat dikembangkan; Mendengar keluhan guru kelas $\mathrm{B}$ dan $\mathrm{C}$ berkaitan dengan ketidaksetujuan terhadap pengelompokkan siswa dan; Pengelompokan kelas diiukuti dengan peningkatan kemampuan guru yang mumpuni terutama ketika menghadapi siswa berkebutuhan khusus.

Bagi Guru kelas, diharapkan mem-berikan pendampingan belajar bagi anak yang masih kurang melalui tambahan pelajaran terutama bagi siswa di kelas rendah; melihat siswa memiliki kelebihan masingmasing yang bisa dikembangkan berdasarkan kecerdasan majemuk dan; Memberikan metode pembelajaran yang lebih bervariasi sehingga anak tidak bosan dan bisa mengakomodasi kebutuhan gaya belajar anak yang berbeda-beda.

Orang tua diharapkan menyadari bahwa setiap anak memiliki kelebihan dan kekurangan masing-masing tidak hanya sebatas pada kemampuan akademik dan terus mendukung anak dalam belajar, sehingga anak dapat mengembangkan diri untuk memaksimalkan potensi yang dimiliki.

\section{DAFTAR PUSTAKA}

Abdurrahman, M. (1999). Pendidikan bagi anak berkesulitan belajar. Jakarta: PT Rineka Cipta.

Adodo. S.O \& Agbaweya, J.O. (2011). Effect of homogenous and heterogeneous ability grouping class teaching on student's interest, attitude and achievement in integrated science. International Journal of Psychology and Counselling, 3(3), 48-54.

Bahar, M. (2015). Student attitudes towards change from ability grouping to heterogeneous grouping at a university class. Mevlana International Journal of Education (MIJE), 5(1),103-114.

Cheung, C \& Rudowicz, E. (2003). Academic outcomes of ability grouping among junior high school students in hongkong. The Journal of Educational Research, March/ April 2003,96(4),241-256.

Chisaka, B.C \& Vakalisa, N.C.G. (2003). Some effects of ability grouping in Harare secondary schools: Aa case study. South African Journal of Education, 23(3), 176 - 180.

Hornby G., Witte C., \& Mitchell D. (2011). Policies and practices of ability grouping in New Zealand intermediate schools. Support for Learning. 26(3),92-96.

Huda, M. (2012). Cooperative learning metode, teknik, struktur dan model terapan. Yogyakarta: Pustaka Pelajar. 
Imron, A. (1994). Manajemen peserta didik di sekolah. Malang: IKIP Malang.

Lie, A. (2004). Cooperative learning: mempraktekkan cooperative learning di ruang-ruang kelas. Jakarta: Gramedia.

Nasution, S. (2003). Berbagai pendekatan dalam proses belajar dan mengajar. Jakarta: Bumi Aksara.
Sugiyono. (2005). Statistika untuk penelitian. Bandung: Alfabeta

Sukardi. (2003). Metodologi penelitian pendidikan kompetensi dan praktiknya. Jakarta: Bumi Aksara.

Wong, M. \& Watkins, D. (2001). Selfesteem and ability grouping: a hong kong investigation of the big fish little pond effect. Educational Psychology, 21(1),79-87 